\title{
Policijas uzdevumi un to īstenošana pirmajos Latvijas valsts pastāvēšanas gados
}

\author{
Dr. iur. Ëriks Trels \\ Rìgas Stradiṇa universitāte, Juridiskā fakultāte, Latvija \\ eriks.trels@gmail.com
}

\section{Kopsavilkums}

Latvijas Republikas Satversmes 89. pantā noteikts: "Valsts atzīst un aizsargā cilvēka pamattiesības saskaṇā ar šo Satversmi, likumiem un Latvijai saistošiem starptautiskajiem lïgumiem."

Kopš Latvijas valsts dibināšanas dienas un līdz pat mūsdienām aktualitāti nezaudē personu un sabiedrības drošības nodrošināšana, cīṇa ar noziedzību, kā arī visu iedzīvotāju tiesību un likumīgo interešu aizsardzība. Šo pienākumu īstenošana ietilpst Valsts policijas uzdevumos.

Rakstā tiek pētīti policijas uzdevumi, to reglamentācija un īstenošana pirmajos Latvijas valsts pastāvēšanas gados, kā arī piedāvāts mūsdienu skatījums uz tā laika problēmām un to risinājumiem.

Atslēgvārdi: policijas tiesības, Latvijas policijas vēsture, policijas uzdevumi, policijas darbỉba.

\section{levads}

Latvijas Republika šogad svinēs savu 100. dzimšanas dienu. Novērojumi liecina, ka, tuvojoties Latvijas valsts dibināšanas simtgadei, sabiedrībā ir palielinājusies interese gan par valsts izveides laika notikumiem, gan par interbellum (latīnu val. - starpkaru) periodu.

Tuvojas arī cita nozīmīga diena - 2018. gada 5. decembrī simt gadu jubileju atzìmēs Valsts policija. 1918. gada 5. decembrī (tieši šì diena ir kḷuvusi par Valsts policijas dibināšanas dienu) Tautas padome pieñēma noteikumus "Pagaidu noteikumi par iekšējās apsardzības organizēšanu” [6]. Šo noteikumu 14. punktā tika noteikts, ka sabiedriskās kārtības un drošības apsargāšanai policijai jāveic vairāki uzdevumi, tostarp jāpārtrauc un jānovērš pārkāpumi, jāaizstāv pilsoniskās tiesības, kā arī jāuztur kārtība sabiedrības lietošanā nodotās vietās. 
Vairāki no šiem uzdevumiem saskan ar mūsdienu normatīvo regulējumu. Likuma "Par policiju" 3. pantā noteikts, ka policijai ir šādi uzdevumi:

- garantēt personu un sabiedrības drošỉbu;

- novērst noziedzīgus nodarījumus un citus likumpārkāpumus;

- atklāt noziedzīgus nodarījumus, meklēt personas, kas izdarījušas noziedzīgus nodarïjumus;

- likumā paredzētajā kārtībā sniegt palīdzību iestādēm, privātpersonām un personu apvienībām to tiesību aizsardzībā un ar likumu noteikto pienākumu realizācijā;

- savas kompetences ietvaros izpildìt administratīvos sodus un kriminālsodus [10].

Pētot policijas uzdevumus un to reglamentāciju Latvijas normatīvajā regulējumā starpkaru periodā, kā arī šì regulējuma attīstību un lietošanas praksi, šìs publikācijas mērḳis ir piedāvāt mūsdienu skatījumu uz tā laika problēmām un šo problēmu risinājumiem.

Veicot pētījumu, tika lietota galvenokārt vēsturiski tiesiskā metode: policijas tiesību attīstîba, policijas uzdevumi un tiesiskais regulējums tika pētîts atbilstoši vēsturiskai hronolog̣ijai. Kā pamatoti norādījis profesors K. Dišlers, šì metode "palīdz noskaidrot tiesisko institūtu būtību, dažreiz arī normu ìsto saturu, aplūkojot viṇu attīstības gaitu" $[21,7]$. Pētījumā tika izmantota arī salīdzinošā metode: salīdzināti normatīvie akti, kas nosaka policijas uzdevumus; analītiskā metode un citas vispārīgās pētniecības metodes, tostarp tiesību normu interpretācijas metodes.

\section{Policijas uzdevumu īstenošana Latvijas atbrīvošanas kara (Brīvības cīnuu) laikā}

1918. gada 18. novembrī tika pasludināta Latvijas valsts nodibināšana. Dienu iepriekš, 1918. gada 17. novembrī, Tautas padomes dibināšanas sēdē vienbalsīgi tika pieņemta Latvijas Tautas padomes politiskā platforma [3]. Minētā dokumenta 6. nodaḷas 1. punktā tika noteikts, ka Latvijas tautas milicija (tautas apsardzības spēks) Pagaidu valdības pārraudzībā organizē tautas apsardzību. 1918. gada 5. decembrī Tautas padome pieñēma citu nozīmīgu dokumentu "Pagaidu noteikumus par iekšējās apsardzības organizēšanu" [6]. Tiesību zinātniece K. Bite šo dokumentu nosauca par pirmās latviskās policijas dibināšanas tiesisko pamatu [17, 29].

Latvijas Republikas neatkarība bija pasludināta, tomēr tās teritorijā turpinājās karadarbība. Par spīti valsts grūtajai situācijai jaunizveidotajā Latvijas policijā sākās organizatoriskais darbs. Preventīvā darba pirmsākums ir policijas atpazīstamība. Jaunizveidotajai policijai nebija pietiekamu līdzekḷu, lai visus policijas darbiniekus nodrošinātu ar formastērpu, un sākotnēji iedzīvotāji policijas kārtībniekus varēja atpazìt pēc īpašas piedurkṇu nozīmes. Rìkojums par policijas formas apgèrbu tika pieñemts 1919. gada 4. novembrī [28]. Tomēr pilnībā atteikties no atpazīšanas zīmēm un ieviest formastērpu Latvijas policija spēja tikai pēc 1926. gada 3. jūnija [14]. 
Karadarbības dēḷ Pagaidu valdībai bija jāpārceḷas uz Liepāju. Arī "policijas organizēšana" uz laiku tika pārtraukta, un iekšējās apsardzības nodaḷas darbinieki reizē ar Pagaidu valdību izbrauca uz Liepāju [33]. Tomēr ne visi policijas darbinieki sekoja valdībai, daži esot slēpušies okupētajā teritorijā vai devušies uz ārzemēm [26]. Šajos grūtajos apstākḷos darba netrūka gan Liepājā palikušajiem policijas spēkiem, gan policijas darbiniekiem no citām Latvijas vietām, kuri rada patvērumu šajā pilsētā.

1919. gada 11. februārī Latvijas Pagaidu valdība izdeva noteikumus "Par kara stāvokli" [8], kas ierobežoja cilvēku tiesības uz sapulču, gājienu un piketu brīvību. Noteikumi skāra arī politiskās brīvības, jo tika ierobežota biedrību un partiju darbība. Policijas darbinieki piedalījās arī visās publiskajās un biedrību sapulcēs, izrīkojumos un priekšlasỉjumos, kā arī citos publiskajos pasākumos. Liepājā pretvalstisku agitāciju un komunistisko propagandu aktīvi veica Latvijas valstiskās neatkarības pretinieki (informatīvais karš nav mūsdienu izgudrojums). Reagēejot uz šo darbību, ar iekšlietu ministra rīkojumu 1919. gada 4. martā tika aizliegta Liepājas krievu avīze Аибавское русское слово, savukārt 17. martā - latviešu laikraksts Liepājas Arodnieks [27].

Sakarā ar izsludināto karastāvokli militārajām iestādēm tika pieškirtas tiesības dot priekšrakstus vietējās administrācijas iestādēm un atcelt to rīkojumus, kā arī atsavināt karaspēkam nepieciešamos materiālos resursus. Karatiesas kompetencei tika pakḷauti daži smagi kriminālnoziegumi, par kuru izdarīšanu civilpersonām saskaṇā ar noteikumu "Par kara stāvokli" 14. punktu draudēja pat nāvessods [8]. Starpkaru periodā izdotajā Latvju mazajā enciklopēdijā ir definēta karatiesa, kas raksturota kā ārkārtēja militārā tiesa, kura "darbojas kara darbības rajonā un kara stāvoklī izsludinātos apgabalos, bet miera laikā var tikt sasaukta dažu politisku lietu iztiesāšanai, iztiesājot tikai tādas lietas, kur noziegums un apsūdzētā vaina nepārprotami skaidri un valsts drošỉba prasa vainīgā tūlītējo sodīšanu”, un tā "tiesā bez iepriekšējās izmeklēšanas, pie kam spriedums izpildāms 24 stundu laikā" $[25,1150]$.

1919. gadā Pagaidu valdības kontrolētajā valsts teritorijā nepietika policijas darbinieku, lai veiksmīgi cīnìtos ar noziedzību. Tad arī radās ideja veidot pilsoṇu pašaizsardzības nodaḷas, kuras vēlāk pārtapa par aizsargu nodạ̦ām [5]. Aizsargu nodaḷu pienākums bija palīdzēt policijai apkarot noziegumus, apsargāt satiksmes cel̦us, aizturēt un nogādāt policijas iestādēs aizdomīgas personas, kā arī veicināt kārtības un drošìbas uzturēšanu savu pagastu robežās. Arī mūsdienās iedzīvotāji var izmantot ar likumu nostiprinātas iespējas piedalīties "pašaizsardzībā", iestājoties Zemessardzē vai kḷustot par policijas palīgiem.

Kad 1919. gada 8. jūlijā Rīgā atgriezās Pagaidu valdība, Liepājā policijas spēki bija jau tiktāl nostabilizējuši savu darbību, ka varēja aktīvi iesaistīties spekulācijas [31;39] un nelikumīgā alkohola aprites apkarošanā [38]. Šis jautājums bija aktuāls arī turpmākajos gados. Piemēram, 1922. gadā par "slepena degvīna izgatavošanu un tirgošanos ar to" tika piemēroti 1869 administratīvie sodi [45].

1920. gada 13. janvārī savu darbu Latvijas teritorijā izbeidza Latvijas strādnieku, bezzemnieku un strēlnieku padomju valdība, un no šĩ brīža visā Latvijas valstī vara pilnīgi 
pārgāja Tautas padomes un tās veidotās Pagaidu valdības rokās. Tomēr līdz mierīgai dzīvei bija vēl tālu.

1920. gada sākumā karadarbība Latvijas teritorijā vēl nebija beigusies, tomēr "policijai bija jāveic miera laika uzdevumi, piemēram, jāizsniedz ațlaujas pārvietoties pa Rīgu nakts laikā, atḷaujas iebraukšanai piefrontes joslā, atḷaujas izbraukšanai uz ārzemēm. [..] bija jānodarbojas arī ar tādiem jautājumiem, kas policijai it kā nav raksturīgi - programmu, afišu, reklāmu cenzēšanu. Iekārtojot jaunās valsts dzīvi uz tiesiskiem pamatiem, policijai nācās būt par iestādi, kura uzrauga, lai visi noteikumi būtu kārtīgi izpildīti un lai valsts un sabiedrības intereses neciestu no atsevišķu indivīdu prettiesiskām darbībām” [17, 31].

Noziedzības līmenis gan toreiz, gan turpmākajos gados bija milzīgs. 1920. gadā tika registrēti 12008 noziegumi (t. sk. 238 slepkavības un 627 laupīšanas), 1921. gadā - 13265 (t. sk. 189 slepkavības un 452 laupīšanas), 1922. gadā - 9563 (t. sk. 174 slepkavības un 248 laupišanas) un 1923. gadā - 7959 noziegumi (t. sk. 103 slepkavības un 148 laupī̌sanas) [34]. Pārskatā par Rīgas prefektūras darbības pirmajiem desmit gadiem, atsaucoties uz statistikas datiem, tika secināts, ka "Latvijas dibināšanas gados nepagāja gandrīz neviena diena, kad nenotika vairākas laupišanas un slepkavības" [35]. Aprakstot to laiku, K. Vilde norāda: "Laupītāju bandas galvenā kārtā darbojās Latgalē pēc lielinieku izdzīšanas. Arī Ventspils, Jelgavas, Rìgas un Talsu apriṇkị policija, ar karaspēka un aizsargu palīdzību, likvidēja laupītāju bandas." [43, 137] Cinṇā ar noziedzību, līdzīgi kā karadarbībā, upuri bija abām pusēm. Pirmos trīs Latvijas valsts pastāvēšanas gados (1919-1921), pildot dienesta pienākumus, krita 23 policijas darbinieki. Tomēr, pateicoties efektīvai policijas darbībai, noziedzības līmenis valstī turpmākajos gados samazinājās.

\section{Policijas uzdevumu īstenošana tiesiskas valsts veidošanas laikā}

1920. gada 17. un 18. aprīlī visā Latvijas teritorijā, izṇemot tos apvidus, kas bija okupēti, notika Satversmes sapulces vēlēšanas. Latvijas tauta ievēlēja savu pirmo parlamentu - Satversmes sapulci. Latvijas pamatlikuma - Latvijas Republikas Satversmes izstrādāšanai bija nepieciešams ilgāks laiks, tāpēc jaunievēlētā Satversmes sapulce pieñēma divus likumus, "kuri kopā sastāda Latvijas otro pagaidu satversmi" [21, 72]. Profesora K. Dišlera ieskatā, pirmā Latvijas pagaidu satversme bija Latvijas Tautas padomes politiskā platforma [3]. Pirmais no pien,emtajiem normatīvajiem aktiem bija "Deklarācija par Latvijas valsti”, un tas sastāvēja tikai no diviem pantiem. Pirmajā pantā tika noteikts, ka "Latvija ir patstāvīga un neatkarīga republika ar demokrātisku valsts iekārtu", savukārt otrajā pantā tika deklarēts, ka "Latvijas valsts suverēnā vara pieder Latvijas tautai" [1]. Otrajā tiesību aktā - "Latvijas valsts iekārtas pagaidu noteikumos" - Satversmes sapulce tika pasludināta par Latvijas valsts suverēnās varas nesēju, un par tās uzdevumu tika noteikts "izstrādāt un izdot valsts pamata un agrārās reformas likumus" [4], paredzot, ka sava uzdevuma veikšanas periodā Satversmes sapulce darbojas kā parlamentārā likumdevēja iestāde. 
Satversmes sapulces galvenais uzdevums bija Latvijas Republikas Satversmes izstrādāšana un pieñemšana. Tika iecerēts Latvijas Republikas Satversmi veidot divās dạ̣ās, pirmajā daḷā ietverot noteikumus, kas regulē valsts iekārtu, bet otrajā daḷā nosakot pilsoṇu tiesības un pienākumus [21, 177-180]. Latvijas Republikas Satversmes pirmā daḷa tika pieņemta 1922. gada 15. februārī [2], bet otrā dalıa tika noraidìta politisko partiju nesaskaṇu dēḷ. Latgales reg̣ionālo partiju pārstāvjus neapmierināja tas, ka netika minēta Latgales autonomija, un sociāldemokrātus neapmierināja, ka netika piel̦autas tiesības uz streiku kā politiskas cīṇas līdzekli [18].

1922. gada 7. novembrī plkst. 12.00 dienā vienlaikus ar Latvijas Republikas Satversmes stāšanos spēkā uz pirmo sēdi sanāca jaunievēlētā Saeima. Šajā dienā Jānis Čakste, kurš pēc septiṇām dienām kḷuva par pirmo Latvijas Republikas prezidentu, svinīgā runā teica, ka Latvijas Republikas Satversme "būs tas pamats, uz kura varēs darboties iestādes un valdības personas labāki un pilnīgāki, nekā tas līdz šim bija iespējams. Mēs cerēsim visi un būsim pārliecībā, ka šì jaunā Satversme mums līdzēs galīgi nodibināt Latvijā likumību un taisnību un līdz ar to tautas labklājību un kārtību" [20, 81-82].

N̦emot vērā, ka Latvijas Republikas Satversmes otrā daḷa netika pieṇemta, svarīgi bija cilvēktiesības nostiprināt citos likumos. 1923. gada 18. jūlijā pienemtajā likumā "Par biedrībām, savienībām un politiskām organizācijām" Latvijas iedzīvotājiem tika nodrošinātas tiesības brīvi apvienoties biedrībās, politiskajās organizācijās un reliǵiskajās apvienībās [7]. Tomēr likumam bija arī negatīvā puse, jo biedrošanās brīvību aktīvi izmantoja arī demokrātiskās Latvijas pretinieki - komunistiskās un kreisās ekstrēmistiskās organizācijas. Piemēram, 1932. gada 19. janvārī Rīgas apgabaltiesā tika reg̣istrēta Latviešu tautas apvienība "Ugunskrusts" [30, 7]. Šì latviešu nacionālistiskā organizācija pauda krasi antisemītiskus uzskatus, kā arī uzstājās pret Latvijā saskaṇā ar Latvijas Republikas Satversmi pastāvošo parlamentāro demokrātiju.

Ar "Ugunskrusta" darbību bija cieši saistīta Sporta un morāliski fiziskās audzināšanas biedrība "Tēvijas sargs". Abās organizācijās valdošā militārā kārtība Iekšlietu ministrijai deva pamatu konstatēt, ka šo organizāciju darbība ir pretrunā ar to statūtiem. 1933. gada 12. aprīlī Rìgas apgabaltiesa pieṇēma lēmumu par Latviešu tautas apvienības "Ugunskrusts" slēgšanu. Tomēr "Ugunskrusts" turpināja savu darbību ar jaunu nosaukumu - 1933. gada 12. maijā Rīgas apgabaltiesa kā politisku organizāciju reǵistrēja Latviešu tautas apvienību "Pērkoṇkrusts". Šì organizācija gandrīz pilnībā pārṇēma "Ugunskrusta" organizatorisko struktūru, biedrus un ideologiju. 1933. gada 15. decembrī Saeima pieṇēma lēmumu par Latviešu tautas apvienības "Pērkoṇkrusts" kā Latvijas demokrātiskai republikai naidīgas organizācijas slēgšanu. Tika apcietināti 35 organizācijas vadības pārstāvji un izdarītas kratīšanas 300 pērkoṇkrustiešu dzīvokḷos. Par spīti aizliegumam "Pērkoṇkrusts" turpināja savu darbību, apvienojoties organizācijās ar citu nosaukumu, no sākuma kā "Jaunā Latvija", bet pēc tās slēgšanas kā Kultūras un sporta veicināšanas biedrība "Dzimtene".

Līdzīga situācija bija ar valstī aizliegto Komunistisko partiju. Tās aktīvisti iefiltrējās citās organizācijās un arodbiedrībās un, ja tās tika slēgtas, atjaunoja savu darbību ar citu 
nosaukumu. Pārskatā par Iekšlietu ministrijas darbību pirmajos piecos valsts pastāvēšanas gados teikts, ka 1922. gadā "komunisti savu ideju realizēšanai ķērās pie sevišḳi rafinētiem paṇēmieniem, un cinna ar viṇiem kḷuva vēl grūtāka kā iepriekšējos gados. Lai slēptos zem legalitātes maskas, komunistu vadošie orgāni diktēja saviem biedriem iestāties legālās organizācijās: partijās un arodbiedrībās, kā arī rūpēties tikt ievēlētam pašvaldību iestādēs un iestāties dienestā valdības iestādēs. Sevišḳi parocīgas komunistiem viṇu ideju popularizēšanai bija arodbiedrības, un tādēl komunisti ar visiem spēkiem ierīkoja Rīgas arodbiedrību centrālbiroju, lai no tā runātu uz strādnieku masām un uzmestos par Latvijas strādnieku faktiskiem vadoṇiem" [33].

1923. gada 18. jūlijā tika pien̦emts likums "Par sapulcēm", kas noteica tiesības sapulcēties "mierīgi un neapbruṇoti", kā arī sapulcēs - vārda un valodas brīvību [11]. Nepieciešamība pēc jauna likuma, kas reglamentētu pasākuma gaitu, parādījās pēc 1923. gada 1. maija notikumiem Rīgā, kad pasākumu laikā notika sadursmes starp sociāldemokrātiem un nacionālistiem, kā arī ar policijas darbiniekiem (divi policijas darbinieki guva traumas). Esplanādē "no sociāldemokrātu tribīnes puses atskanēja atsevišḳi revolvera šāvieni" [36]. Sadursmēs kopumā bija cietušas 16 personas, no tām divas ar šautām brūcēm tika ievietotas slimnīcās. Šo notikumu izmeklēšanai tika iecelta komisija Ministru prezidenta J. Pauḷuka vadībā, kurā piedalījās arī iekšlietu, ārlietu, tieslietu un aizsardzības ministrs [37]. Pulcēšanās brīvība valstī tika plaši izmantota. Statistikas dati liecina, ka 1923. gadā Rīgas pilsētas teritorijā vien policijas klātbūtne tika nodrošināta 1104 pasākumos [41].

1929. gada 17. oktobrī Ministru kabinets pieñēma Policijas iekārtas noteikumus [13]. Saskañā ar noteikumiem policijas uzdevums bija "rūpēties par noziedzību novēršanu, pārtraukšanu un vispār apkarošanu, gādāt par sabiedrības drošỉbas, kārtības, tikumības un miera uzturēšanu, palīdzēt posta un nelaimes gadījumos, kā arī pārzināt sanitāro uzraudzību un izpildìt citus ar attiecīgajiem likumiem un noteikumiem uzliktus pienākumus". Policija tika iedalīta Kārtības policijā, Kriminālā policijā un Politiskā policijā. Tika atrunāts, ka Dzelzcel̦a policija ietilpst Kārtības policijas sastāvā.

Saskañā ar noteikumu 10. punktu Kārtības policijas uzdevums bija apkarot noziedzību, gādāt par sabiedriskās drošības un kārtības uzturēšanu un izpildīt citus ar attiecīgiem likumiem, rīkojumiem un saistošiem noteikumiem uzliktus pienākumus. Tika noteikts, ka policijai “jāapcietina bez sevišķas pavēles: acīm redzami piedzērušie, garā slimie un citi, kuru atrašanās brīvībā saistìta ar briesmām viṇiem pašiem vai citiem pilsoṇiem" [13].

Policijas darbu ar iedzīvotājiem labi ilustrē Rīgas prefektūras darbības rezultāti. Tolaik apkopotie statistiskie dati liecina:

“1919. gadā Rīgas policija ir saṇēmusi un dažādās lietās izpildījusi 55000 ienākušos rakstus. Turpretim 1928. gadā ienākušo rakstu kopskaits ir pieaudzis 10-kārtīgi un sniedzas pie 507 043. Bet visos 10 pastāvēšanas gados Rīgas pils. policija ir izpildījusi pāri par 4,5 miljona ienākušos rakstus [..]. Tajā pat laikā Rīgas policija ir sarakstījusi 164 474 protokolus, no kuriem 38564 ir par obligatorisko noteikumu neievērošanu, 
24 085 par piedzeršanos un trokšņošanu, 12962 par miera un kārtības traucēšanu, 14641 par nelaimes gadỉjumiem utt. Jāatzīmē, ka policijas sarakstāmo protokolu skaits aizvien pieaug, jo 1919. gadā bija sarakstīti tikai 6262 protokoli, 1925. gadā - 19 142, bet 1928. gadā jau - 25484 protokoli” [35].

Policijas iekārtas noteikumu 24. punktā noteikts, ka Kriminālajai policijas uzdevums ir atklāt un apkarot kriminālnoziegumus [13]. Rakstā "Par iedzīvotāju drošību valstī 1928. gadā", kas 1930. gada 28. janvārī tika publicēts Iekšlietu Ministrijas Vēstnesī, norādīts, ka "Kriminālpolicijas darbība paliek arvien sekmīgāka" un "slepkavību skaits 1928. gadā samazinājies par 12,7\%” (1928. gadā bija 196, savukārt 1929. gadā - 170 slepkavības) [32]. Tālāk rakstā ir uzsvērts, ka 40\% no visām izdarītām slepkavībām notikušas Latgalē un ka 70 gadijumos slepkava bijis alkohola reibuma stāvoklī. Tajā pašā laikā par 12 \% bija pieaudzis izdarīto laupīšanu skaits (1928. gadā - 126, savukārt 1929. gadā - 140 laupīšanas). Galvaspilsēta ar 41 laupiššnu bija ierindojusies pirmajā vietā pēc laupiššnu skaita. Zādzību skaits attiecīgajā periodā palika gandrīz nemainīgs (1928. gadā - 12 581, savukārt 1929. gadā - 13059 zādzības). "Kriminālpolicijas darbỉbu raksturo atklāto noziegumu skaits. Slepkavības atklātas: 1929 . gadā $-84,1 \%, 1928$. gadā $-81,6 \%$, 1927. gadā - 80,7\%. Laupī̌nanas atklātas: 1929 . gadā - 79,2\%, 1928. gadā - 73\%,1927. gadā - 67,1 \%. Zādzības atklātas: 1929. gadā $-72 \%, 1928$. gadā $-68,1 \%, 1927$. gadā - 71,5\%” [32]. Pirmajos desmit valsts pastāvēšanas gados Rīgas prefektūras "aresta telpās, bez iecirkṇos aizturētiem, līdz 1929. gadam ievietotas 17081 persona (to starpā arī kriminālpolicijas aizturētie noziedznieki)". Savukārt K. Vilde publikācijā par policijas veikumu tās darbu noziegumu atklāšanā raksturo pozitīvi, rakstot, ka "noziegumu atklāšana norit sekmīgi, jo neatklāts paliek visai neievērojams svarīgāko noziegumu skaits" [43, 137].

Politiskās policijas uzdevums saskaṇā ar Policijas iekārtas noteikumu 32. punktu bija "atklāt un apkarot noziedzības, kas vēršas pret valsts demokrātisko iekārtu un drošību" [13]. Rakstā "Par iedzīvotāju drošību valstī 1928. gadā" uzsvērts, ka Politiskās policijas darbs šajā jomā "bijis ḷoti sekmīgs pretvalstiskas - lielinieciskās - kustības apkarošanā. Pēc kreiso arodbiedrību slēgšanas 1928. gadā šì kustība sāka iet uz leju, jo zuda iespēja izplatìt komunisma idejas legālā ceḷā strādnieku masās. Visas pūles atjaunot šādu darbību, pateicoties politiskās policijas enerğiskai darbībai, ir bijušas veltas. Tāpat daudzo nelegālo komunistisko organizāciju atklāšana un svarīgu Kominterna aǵentu apcietināšana atstājusi lielu iespaidu nelegālā kustībā, to gandrīz iznīcinot" [32].

Kā jau tika minēts, policija tolaik bija iesaistìta arī tai neraksturīgu uzdevumu īstenošanā. Lìdz 1929. gadam Rīgas policija bija izsniegusi vairāk nekā 600000 Latvijas pasu, jo daudzi bija nozaudējuši savus personu apliecinošus dokumentus:

"[..] nozaudēto pasu un citu dokumentu skaits vien no 1920. līdz 1928. gadam sniedzas pie 34 834, t. i., Rīgā ik dienas, caurmērā n,emot, ir pazaudētas pa 11 pases vai citu dokumentu." [35]

Tajā pašā laikā tika izsniegtas uzturēšanās, izbraukšanas un citas aț̣aujas ārzemniekiem: "Latvijas pavalstniecībā uzṇemti 8166 ārvalstnieki un izraidìti kā nevēlami 
un Latvijai kaitīgi - 3813 ārvalstnieki." [35] Vienai no Rīgas prefektūras struktūrvienībām - Adrešu birojam - bija uzticēta iedzīvotāju dzīvesvietas reǵistrācija. Statistiskie dati liecina, ka Adrešu birojs "pastāvēšanas laikā ir reǵistrējis 786111 Rīgā iebraukušas personas, bez kurām vēl reǵistrētas: 435918 personas, kā dzīvokḷus mainījušas, 285 679, kā dokumentus (pases) mainījušas, 270 860, kā iebraukušas viesnīcās, 36 693, kā iebraukuši emigranti, un 16360 personas, kā uzṇemtas slimnīcās. Tātad Adrešu birojā līdz 1929. gada 1. janvārim bija pierakstîta pavisam 1831621 persona, bet tajā pat laikā bija izrakstītas 1240027 personas, no kurām 400 971, kā aizbraukušas no Rīgas, 266 118, kā aizbraukušas no viesnīcām, 268 576, kā dzīvokḷus mainījušas” [35]. Papildus minētajam Rīgas policijas darbības efektivitāti un funkciju dažādību apliecina šādi dati:

"No 1919. līdz 1929. gadam visos Rīgas prefektūras iecirknos: ienākuši 3371124 raksti un 95910 telefonogrammas, pierakstīti 136874 un izrakstīti 98835 ārzemnieki, noturētas 11 174 sapulces, 38021 izrīkojums, izdotas 30557 apliecības, sarakstīti 164 474 protokoli un iekasēti Ls 10258670 dažādu nesamaksātu nodokḷu un sodu." [35]

Minētie uzdevumi tika īstenoti papildus policijas uzdevumiem, kas tradicionāli ir policijas kompetencē. Policijas darbības efektivitāte nemazinājās arī turpmākajos gados.

\section{Policijas uzdevumu īstenošana autoritārā valsts režīma priekšvakarā}

1933. gada 24. aprīlī Latvijas Republikas Saeima pienēma Sodu likumu [16]. Tieslietu ministrijā tika izveidota komisija, kurā darbojās 35 "priekšstāvji no visiem ieinteresētajiem resoriem” [42]. Astoṇu gadu laikā komisijas darbības rezultātā tika izstrādāts Latvijas Sodu likuma projekts, kam "Saeimas juridiskā apakškomisija pārstrādāja projekta vispārējo dal̦u" [22, 196]. Tiesību zinātnieks A. Niedre pamatoti norāda, ka "ar 1933. gada Sodu likumu tika saskaṇoti principiālie jautājumi, kas attiecas uz Krimināllikuma saturu, gan par vainas formām, līdzdalības jautājumiem, fiziskas personas atbildību juridiskās personas lietās, naudas sodu piemērošanu un aizstāšanu, gan arī par noziedzīgiem nodarỉjumiem pret personu, pret īpašumu, valsts institūciju dienestā utt. Krimināllikuma projekta normas pēc to būtības salīdzinātas ar Vācijas, Zviedrijas, Dānijas Kriminālkodeksa atbilstošām normām" [29]. Jāpiebilst, ka tolaik valodas jomā valdīja loti demokrātiski noteikumi. Saeimas kārtības rullis ḷāva deputātiem uzstāties ar runām vācu un krievu valodā [15]. Spilgtākais šādas politikas piemērs ir Sodu likums, kura likumprojekts tika izstrādāts krievu valodā. Minētais "fakts spilgti raksturo grūto pāreju uz latviešu valodu Latvijas Republikas jurisprudencē, jo bija jāveic ievērojams darbs tiesību terminoloǵijas izstrādāšanā latviešu valodā" [24, 264]. Papildus jāatzīmē, ka Sodu likumā nebija paredzēts nāves sods, kas tolaik bija ḷoti progresīvs solis, jo daudzās civilizētās valstīs šāds sods pastāvēja un turpina pastāvēt joprojām.

Lai nostiprinātu tiesisko kārtību valstī, Ministru kabinets 1933. gada 27. aprīlī apstiprināja noteikumus "Policijas iekārta". Noteikumu 1. punktā tika reglamentēti 
uzdevumi policijai. Tai tika uzdots "rūpēties par noziedzīgu nodarījumu novēršanu, pārtraukšanu un vajāšanu, gādāt par sabiedriskās drošības, kārtības, miera un tikumības uzturēšanu, palīdzēt posta un nelaimes gadījumos, kā arī izpildìt citus ar attiecīgiem likumiem, noteikumiem un instrukcijām uzliktus pienākumus" [12].

Līdzīgi kā 1929. gada 17. oktobra Policijas iekārtas noteikumi [13], arī jaunie noteikumi pieškīra Kārtības policijai, Kriminālai policijai un Politiskai policijai dažādu kompetenci. Jāatzīmē, ka minēto struktūrvienību kompetence un noteiktie uzdevumi sakrīt ar mūsdienu normatīvajā regulējumā noteikto [10]. Noteikumu 9. punktā tika noteikts, ka

"Kārtības policijas uzdevums ir apkarot pārkāpumus, noziegumus un smagus noziegumus, gādāt par sabiedriskās drošības, kārtības, miera un tikumības uzturēšanu un izpildìt citus ar attiecīgiem likumiem, noteikumiem un instrukcijām uzliktus pienākumus. Viṇai jāapcietina bez sevišķas pavēles acīmredzami piedzērušies, garā slimi un citi, kuru atrašanās brīvībā saistīta ar briesmām viṇiem pašiem vai citiem pilsoṇiem.” [13]

Ministru kabineta 1933. gada 27. aprīla noteikumu "Policijas iekārta" 21. punktā noteikts, ka Kriminālajai policijai ir uzdevums "apkarot un atklāt smagus noziegumus, kā arī noziedzīgus nodarījumus, kuri prasa ilgstošu novērtēšanu” [13]. Savukārt noteikumu 27. punktā minēts, ka "Politiskās policijas uzdevums ir atklāt un apkarot noziedzīgus nodarījumus, kas vēršas pret valsts iekārtu un drošību" [13].

Policijas uzdevumu īstenošanas kvalitāti, neapšaubāmi, ietekmē policijas darbinieku izglìtības līmenis. Diemžēl jākonstatē, ka starpkaru periodā Latvijā policijas darbinieku izglìīibas līmenis bija zems. Statistiskie dati liecina, ka 1930. gadā no 2393 policijas darbiniekiem pabeigta augstākā izglìtība bijusi tikai četriem, 1931. gadā - sešiem no 2403, 1932. gadā - septiṇiem no 2432, 1933. gadā - sešiem no 2397, 1934. gadā - septiṇiem no 2409 , 1935. gadā - sešiem no 2452, 1936. gadā - 10 no 2589, 1937. gadā - 10 no 2614 darbiniekiem $[44,107]$.

Neapmierinoša situācija bijusi arī ar policijas darbinieku arodizglītību.

“1936. gadā no 2412 strādājošajiem prefektūru, apriṇ̣̂u policijas un Dzelzceḷu policijas iecirkṇu priekšniekiem un zemākiem ārējā dienesta darbiniekiem pilnu policijas skolas kursu bija beiguši 1328 (55\%) cilvēki: (1) iecirkṇu priekšnieki - 5 no 76, (2) lauku policijas iecirkṇu Kriminālpolicijas uzraugi - 24 no 54, (3) rajonu uzraugi - 109 no 223,

(4) vecākie policijas kārtībnieki - 489 no 806, (5) jaunākie kārtībnieki - 701 no 1227." $[44,107]$.

Šie dati liecina, ka tikai $7 \%$ no visiem policijas iecirkṇu priekšniekiem bijusi arodizglitîba.

Vērtējot situāciju valstī kopumā, jāatzīmē, ka starpkaru periodā "nedaudz vairāk par 10 gadiem ilgusī demokrātija nespēja nodrošināt valsts tautsaimniecības uzplaukumu, tā vietā zēla korupcija, finanšu un politiski skandāli" [23, 49]. Arī Latvijas politiskie spēki tolaik bija l,oti sadrumstaloti, kas negatīvi ietekmēja valsts stabilitāti. Starpkaru periodā Latvijas politiḳi nevarēja izveidot stabilu valdību, par ko liecina fakts, ka 14 gadu laikā bija 13 dažādas valdības [40, 386-396]. 
1934. gadā naktī no 15. uz 16. maiju Ministru prezidenta Kārḷa Ulmaṇa vadībā Latvijas Republikā notika apvērsums. Parlamentārā republika beidza pastāvēt, un to, rupji pārkāpjot Latvijas Republikas Satversmi, nomainīja autoritārs valsts režīms. Armijas dal̦as, policija un aizsargi, rīkodamies kopīgi, neuzkrītoši ien̦ēma visus stratēgiski svarīgos objektus: Saeimas namu, valdības iestādes, tiltus, pastu, telegrāfu un citus objektus. Apvērsums notika klusi un mierīgi, bez asinnaina terora. Apvērsumu veicināja vairāki apstākḷi: nopietna politiskā krīze; daudzo politisko partiju sašḳeltā Saeima; plašs korupcijas rādītājs parlamentārajā Latvijā; tas, ka apvērsumu vadīja Ministru prezidents, tātad augstākās izpildvaras pārstāvis; to atbalstīja policijas, armijas un aizsargu organizāciju vairākums; tautas neiejaukšanās.

Pēc apvērsuma tika apturēta visu politisko partiju darbība, un "partiju likvidēšanu liela daḷa sabiedrības pat apsveica" [24, 264-267], tika padzìta Saeima un vēlētās pašvaldību institūcijas, apcietināti demokrātijas iekārtas aktīvākie piekritēji. Tika nodibināta stingra cenzūra - 1934. gadā tika slēgti 54 laikraksti un 14 žurnāli $[19,206]$. Tika aizliegtas politiskās sapulces un demonstrācijas. Visā Latvijā uz sešiem mēnešiem tika izsludināts karastāvoklis, kas pēc tam vairākkārt tika pagarināts.

Autoritārais režīms Latvijā pastāvēja diezgan neilgi - no 1934. gada 15. maija līdz 1940. gada 20. jūnijam. Kaut arī K. Ulmaņa autoritārā režīma pilsonisko un politisko tiesību ierobežojumi negatīvi ietekmēja valsts iedzīvotājus, tomēr šīs darbības nemaz nevar salīdzināt ar tiem tiesību pārkāpumiem, kurus veica totalitārie režīmi, kas sekoja turpmākajos gados.

\section{Secinājumi}

Latvijas Republika tika dibināta kā apvienota, patstāvīga, neatkarīga un uz demokrātiskiem pamatiem balstīta republika. Lìdzīgi kā visas valsts darbỉba, arī Latvijas policija tika radīta un turpmāk attīstījās, pamatojoties uz tiesību aktos nostiprinātām normām.

Pozitīvi var vērtēt policijas darba îstenošanu Latvijā starpkaru periodā, par ko liecina samazināta kadru mainība, profesionāla darbība, augsts atklāto noziegumu skaits, sabiedrības uzticība policijai un policistu vēlme strādāt valsts labā $[17,33]$.

Atjaunojot Latvijas valstisko statusu 1990. gada 4. maijā ar deklarāciju "Par Latvijas Republikas neatkarības atjaunošanu" [9], tika veikta arī visas tiesību sistēmas reforma un tās harmonizācija un attīstîba, kura balstās uz cilvēktiesību normu ievērošanu. Latvija kḷuva par neatkarīgu demokrātisko republiku, bet demokrātiskās valsts funkcionēšanas neatnemama sastāvdaḷa ir cilvēktiesību ievērošana un visu iedzīvotāju labklājība un drošība.

Pārskatā par Rīgas prefektūras darbības pirmajiem desmit gadiem pilnīgi pamatoti tika atzīmēts, ka miers, kārtība un drošỉba, par ko gādā Valsts policija, pēc valsts dibināšanas Latvijas iedzīvotājiem bija l̦oti nepieciešama [35]. Laikiem mainoties, šîs trīs galvenās lietas - miers, kārtība un drošība - joprojām ir policijas darbības objekti un joprojām ir svarīgas un nepieciešamas katram valsts iedzìvotājam kā Latvijā, tā arī citur pasaulē. Mūsdienu policijai jāturpina pirmskara tradīcijas, īstenojot savus uzdevumus visas sabiedrības interesēs. 


\section{Tasks of the Police and Implementation in the First Years of Existence of the Republic of Latvia}

\section{Abstract}

Section 89 of the Constitution of the Republic of Latvia states: "The State shall recognise and protect fundamental human rights in accordance with this Constitution, laws and international agreements binding upon Latvia."

The goal of the article is to explore tasks of the police and their implementation in the first years of the existence of the Republic of Latvia, to offer the definitions of the concepts, make conclusions and proposals for further development of the Police law.

During the study, it was found out that a number of researches developed in the first years of existence of the Republic of Latvia have not lost their topicality even today. Based on the findings obtained in the course of these works and using the modern terminology, in the article there are given definitions of some concepts in the field of Police law.

Keywords: police law, history of Latvia police, tasks of the police, police activity, policing.

\section{Avoti un literatūra}

\section{Tiesību akti}

1. Deklarācija par Latvijas valsti: Latvijas valsts deklarācija: pieṇemta 27.05.1920. No: Likumu krājums. 4, 31.08.1920.

2. Latvijas Republikas Satversme: Latvijas valsts likums: pieṇemta Satversmes sapulcē 15.02.1922. Latvijas Vēstnesis. 43, 01.07.1993.

3. Latvijas Tautas padomes politiskā platforma: Latvijas Tautas padomes dokuments: pienemts 17.11.1918. Pagaidu Valdības Vèstnesis. 1, 14.12.1918.

4. Latvijas valsts iekārtas pagaidu noteikumi: Latvijas Republikas noteikumi: pieṇemti 01.06.1920. No: Likumu kräjums. 4, 31.08.1920.

5. Noteikumi par aizsargu nodal̦ām pagastos: Latvijas Pagaidu valdības noteikumi: pieņemti 20.03.1919. Latvijas Sargs. 51, 21.03.1919.

6. Pagaidu noteikumi par iekšējās apsardzības organizēšanu: Latvijas Pagaidu valdības noteikumi: pieñemti 05.12.1918. Pagaidu Valdības Vēstnesis. 1, 14.12.1918.

7. Par biedrībām, savienībām un politiskām organizācijām: Latvijas Republikas likums: pieṇemts 18.07.1923. No: Likumu krājums. 87, 1923.

8. Par kara stāvokli: Latvijas Pagaidu valdības noteikumi: pieṇemti 11.02.1919. Latvijas Sargs. 21, 13.02.1919.

9. Par Latvijas Republikas neatkarības atjaunošanu: LPSR AP deklarācija: pieṇemta 04.05.1990. Latvijas PSR Augstākās Padomes un Valdības Ziṇotājs. 20, 17.05.1990.

10. Par policiju: Latvijas Republikas likums: pieṇemts 04.06.1991. Latvijas Republikas Augstākās Padomes un Valdības Ziṇotājs. 31/32, 15.08.1991. 
11. Par sapulcēm: Latvijas Republikas likums: pieṇemts 18.07.1923. No: Likumu kräjums. 87, 1923. 12. Policijas iekārta: Latvijas Republikas noteikumi: pieṇemti 27.04.1933. Valdības Vēstnesis. 95, 29.04.1933.

13. Policijas iekārtas noteikumi: Latvijas Republikas noteikumi: pienemti 17.10.1929. No: Likumu krājums. 220, 1929.

14. Policijas un robežapsardzības dienesta apgérbu apraksts: Iekšlietu ministrijas noteikumi Nr.11238: pienemti 03.06.1926. Valdības Vēstnesis. 129, 14.06.1926.

15. Saeimas kārtības rullis: pieṇemts 10.04.1929. Valdības Vēstnesis. 79, 10.04.1929.

16. Sodu likums: Latvijas Republikas likums: pieṇemts 24.04.1933. No: Likumu krājums. 134, 1933.

\section{Literatūra}

17. Bite, K. Policijas iestāžu vēsture Latvijā (1918-1940). No: Vēsture: avoti un cilvēki. XIX zinātniskie lasījumi. Vēsture XIII. I. Saleniece, atb. red. Daugavpils: Daugavpils Universitātes akadēmiskais apgāds "Saule", 2010.

18. Blūzma, V. Tiesiskās valsts pirmsākumi Latvijā. Latvijas Vēsture. 1, 1999.

19. Cilvēktiesības pasaulē un Latvijā. I. Ziemeles red. Rīga: Izglītības soḷi, 2000.

20. Čakste, J. Taisnība vienmēr uzvarēs. Atzin,as, runas, dokumenti, raksti, vēstules. Rīga: Jumava, 1999.

21. Dišlers, K. Ievads Latvijas valststiesību zinātnē. Rīga: A. Gulbis, 1930.

22. Dravenieks, A. Latvijas valsts un tiesību vēsture. Rīga: Latvijas Policijas akadēmija, 2006.

23. Eglïtis, V. Ievads konstitūcijas teorijā. Rīga: Latvijas Vēstnesis, 2006.

24. Latvijas tiesību vēsture (1914-2000). D. A. Lēbera red. Rīga: Fonds "Latvijas vēsture", 2000.

25. Latvju mazā enciklopēdija. 1. sēj. A. Bīlmaṇa virsred., S. Melnalkšṇa red. Rīga: Grāmatu draugs, 1932.

26. Mūsu policijas noorganizēšanas darbs (1918-1920). Policijas Vēstnesis. 19, 06.07.1923.

27. Mūsu policijas noorganizēšanas darbs (1918-1920). Policijas Vēstnesis. 28, 07.08.1923.

28. Mūsu policijas noorganizēšanas darbs (1918-1920). Policijas Vēstnesis. 60, 27.11.1923.

29. Niedre, A. Par Latvijas krimināltiesībām, tuvojoties Eiropas kritērijiem. Latvijas Vēstnesis. 4, 09.01.2001.

30. Paeglis, A. Pērkoṇkrusts pār Latviju. Rīga: Zvaigzne ABC, 1994.

31. Par biržas noturēšanu. Kurzemes Vārds. 36, 27.07.1919.

32. Par iedzīvotāju drošību valstī 1928. gadā. Iekšlietu Ministrijas Vēstnesis. 366, 28.01.1930.

33. Pārskats par Iekšlietu ministrijas darbību mūsu valsts 5 gadu pastāvēšanas laikā. Policijas Vēstnesis. 57, 16.11.1923.

34. Pārskats par policijas darbību noziegumu apkarošanas lietās par laiku 1920.-1923. g. Policijas Vēstnesis. 59, 23.11.1923.

35. Rīgas prefektūras 10 gadu darbība 1919.-1929. g. Iekšlietu Ministrijas Vēstnesis. 311, 02.07.1929.

36. Rīgas prefektūrā. Policijas Vēstnesis. 2, 04.05.1923.

37. Rīgas prefektūrā. Policijas Vēstnesis. 3, 08.05.1923.

38. Slepenu degvīna tirgotavu Kriminālpolicija uzgājusi pie Annas tirgus. Kurzemes Vārds. 37, 29.07.1919.

39. Spekulantiem atṇemtas pārtikas vietas. Kurzemes Vārds. 37, 29.07.1919.

40. Šilde, Ā. Latvijas vēsture 1914-1940. Stokholma: Daugava, 1976.

41. Tabelarisks pārskats par Rīgas pilsētas policijas iecirkṇu darbību 1923. gadā. Policijas Vēstnesis. 39, 16.05.1924. 
42. Tieslietu ministrijas darbība krimināltiesībās, Latvijas pastāvēšanas pirmājos 10 gados. Jurists. 7, 01.12.1928.

43. Vilde, K. Valsts drošība. No: Latvija desmit gados: Latvijas valsts nodibināšanas un viṇas pirmo 10 gadu darbības vēsture. M. Ārona red. Rīga: Jubilejas komisijas izlaidums, 1928.

44. Žīgure, A. Latvijas policijas vēsture. 3. sēj. Rīga: Fakts, 1998.

45. 1922. gadā uzliktie administratīvie sodi. Policijas Vēstnesis. 8, 29.05.1923. 